\title{
CONHECIMENTO SOBRE PLANTAS MEDICINAIS ENTRE AGRICULTORES DE BASE ECOLÓGICA DA REGIÃO SUL DO RIO GRANDE DO SUL*
}

\author{
Teila Ceolin¹ ${ }^{1}$ Rita Maria Heck², Rosa Lía Barbieri
}

\begin{abstract}
RESUMO: É entre os membros da família que se propagam informações orais quanto aos hábitos e os cuidados com a saúde, como o uso das plantas medicinais. Esta pesquisa objetivou investigar o conhecimento relacionado às plantas medicinais entre as gerações familiares e conhecer as redes de transmissão adotadas entre os deste conhecimento, dos agricultores de base ecológica da região Sul do Rio Grande do Sul. Consiste em um estudo qualitativo, descritivo e exploratório, o qual foi realizado com 8 famílias de agricultores ecológicos, totalizando 19 entrevistados, residentes nos municípios de Pelotas, Morro Redondo, Canguçu e Arroio do Padre. A coleta de dados ocorreu entre janeiro e maio de 2009. Foram utilizados como instrumentos a entrevista semiestruturada, a construção de genograma e ecomapa, a observação das plantas com registro fotográfico e o georreferenciamento. Os dados foram analisados e agrupados em três temáticas: levantamento etnobotânico das plantas medicinais citadas pelos entrevistados; contextualização dos agricultores do estudo e o saber sobre as plantas medicinais nos diferentes grupos familiares. Entre os entrevistados, 16 eram mulheres, destacando a importância destas na transmissão do conhecimento entre as gerações familiares. Foram citadas, pelos entrevistados, 196 plantas medicinais, entre nativas do Rio Grande do Sul e exóticas do Estado, e 7 elixires. O nome popular atribuído para algumas plantas medicinais variou entre cada família pesquisada, ocorrendo também atribuição do mesmo nome a plantas de gêneros diferentes. A família foi referida como principal fonte na transmissão do conhecimento em relação às plantas medicinais, seguida de grupos de mulheres e/ou igreja da comunidade, entre outros. A maioria dos sujeitos relatou realizar, primeiro, o tratamento com as plantas medicinais para depois buscar o serviço formal de saúde. As plantas são utilizadas como uma prática no cuidado à saúde entre os agricultores, os quais trocam seus conhecimentos entre si e com os demais membros da comunidade. A Enfermagem, na busca do cuidado integral, deve compreender o contexto cultural no qual o indivíduo e a sua família estão inseridos, suas práticas de cuidado e as redes de transmissão deste saber popular.
\end{abstract}

PALAVRAS-CHAVE: Cultura; Saúde da família; Cuidados de enfermagem; Plantas medicinais

\section{KNOWLEDGE ABOUT MEDICINAL PLANTS AMONG ECOLOGICAL FARMERS IN SOUTHERN RIO GRANDE DO SUL}

\begin{abstract}
It is among the family members that oral information about the habits and health care are spread, and also the use of medicinal plants. This study aimed to analyze the transmission of knowledge related to medicinal plants among family generations and know the transmission networks of knowledge, involving ecological farmers in Southern Rio Grande do Sul are. The study of qualitative, descriptive and exploratory approach, was conducted with 8 ecological farm families, in a total of 19 respondents living in the counties of Pelotas, Morro Redondo, Canguçu and Arroio do Padre. Data collection occurred between January and May 2009. Were used semi-structured interviews, the construction of the genogram and eco-map as tools, as well as the observation of plants with photographic record and georeferencing. Data were analyzed and grouped into three themes: an ethnobotanical survey of medicinal plants cited by the interviewees; contextualization of farmers in study, and the knowledge about medicinal plants in different family groups. Among those subjects interviewed, 16 were women, highlighting their importance in the transmission of knowledge between family generations. The respondents cited 196 medicinal plants, some of them were native from the Rio Grande do Sul State and others were exotics, and 7 elixirs. The popular name given to some medicinal plants varied from each family investigated, occurring also the assignment of the same name for plants of different genera. The family was referred to as the main source in the transmission of knowledge about medicinal plants, followed by women's groups and / or church community, among others. Most subjects reported that they first enroll a treatment with medicinal plants, and after they seek the formal health service. Plants are used as a practice in health care among farmers who exchange their knowledge among themselves and with other community members. Nursing, in the search for a comprehensive care, must understand the cultural context in which the individual and his family are inserted, their care practices and the transmission networks of popular knowledge. KEYWORDS: Culture; Family health; Nursing care; Plants, medicinal.
\end{abstract}




\section{CONOCIMIENTO SOBRE PLANTAS MEDICINALES ENTRE AGRICULTORES DE BASE ECOLÓGICA DE LA REGIÓN SUR DE RÍO GRANDE DO SUL}

RESUMEN: Es entre los miembros de la familia que se propagan informaciones oralmente cuanto a los hábitos y los cuidados con la salud, como el uso de plantas medicinales. Esta investigación tuvo como objetivo el conocimiento relacionado a las plantas medicinales entre las generaciones familiares y conocer las redes de transmisión adoptadas entre ellos de este conocimiento, de los agricultores de base ecológica de la región Sur de Río Grande del Sur. Consiste en un estudio cualitativo, descriptivo y exploratorio, el cual fue realizado con 8 familias de agricultores ecológicos, totalizando 19 entrevistados, residentes en los municipios de Pelotas, Morro Redondo, Canguçu y Arroio do Padre. La colecta de los datos ocurrió entre enero y mayo del 2009. Fueron utilizados como instrumentos la entrevista semiestructurada, la construcción de genograma y ecomapa, la observación de las plantas con registro fotográfico y el georreferenciamiento. Los datos fueron analizados y agrupados en tres temáticas: levantamiento etnobotánico de las plantas medicinales citadas por los entrevistados; contextualización de los agricultores del estudio y el conocimiento sobre las plantas medicinales en los diferentes grupos familiares. Entre los entrevistados, 16 eran mujeres, destacando la importancia de éstas en la transmisión del conocimiento entre las generaciones familiares. Fueron citadas por los entrevistados 196 plantas medicinales, entre nativas de Río Grande del Sur y exóticas del Estado, y 7 elixires. El nombre popular atribuido para algunas plantas medicinales varió entre cada familia investigada, ocurriendo también atribución del mismo nombre a plantas de géneros diferentes. La familia fue referida como principal fuente en la transmisión del conocimiento en relación a las plantas medicinales, seguida de grupos de mujeres y/o iglesia de la comunidad, entre otros. La mayoría de los individuos relató realizar primero el tratamiento con las plantas medicinales, para después buscar el servicio formal de salud. Las plantas son utilizadas como una práctica en el cuidado de la salud, entre los agricultores, los cuales intercambian los conocimientos entre sí con los demás miembros de la comunidad. La enfermería, en su búsqueda del cuidado integral, debe comprender el contexto cultural en el cual el individuo y su familia están insertados, sus prácticas de cuidado y las redes de transmisión de este conocimiento popular.

PALABRAS CLAVE: Cultura; Salud de la familia; Atención de enfermería; Plantas medicinales.

\footnotetext{
*Resumo de Dissertação de Mestrado apresentada ao Programa de Pós-Graduação em Enfermagem, Área de concentração: Práticas Sociais em Enfermagem e Saúde (Linha de pesquisa: Práticas de Gestão, Educação, Enfermagem e Saúde). Universidade Federal de Pelotas - UFPel. Projeto: Plantas bioativas de uso humano por famílias de agricultores de base ecológica na Região Sul do RS, financiado pelo CNPq.

${ }^{1}$ Enfermeira. Mestre em Enfermagem.

${ }^{2}$ Enfermeira. Doutora em Enfermagem. Professor Adjunto da Faculdade de Enfermagem da UFpel. Orientadora.

${ }^{3}$ Bióloga. Doutora em Genética e Biologia Molecular. Pesquisadora da Embrapa em Clima Temperado. Co-orientadora.
}

Autor correspondente:

Rita Maria Heck

Universidade Federal de Pelotas

Rua Mario Xavier Oliveira, 77 - 96020-490 - Pelotas-RS, Brasil

Recebido: 31/01/10

E-mail: heck@ufpel.tche.br

Aprovado: 20/02/10

Cogitare Enferm 2010 Jan/Mar; 15(1):169-70 